University of Nebraska - Lincoln

DigitalCommons@University of Nebraska - Lincoln

Publications, Agencies and Staff of the U.S.

Department of Commerce

U.S. Department of Commerce

$10-2006$

\title{
The Phylogenetic Relationships and Biogeography of True Porpoises (Mammalia: Phocoenidae) Based On Morphological Data
}

\author{
Liliana Fajardo-Mellor \\ San Diego State University \\ Annalisa Berta \\ San Diego State University \\ Robert L. Brownell Jr. \\ Southwest Fisheries Science Center, rlbcetacea@aol.com \\ Claudia Boy \\ Centro Austral de Investigaciones Cient'Ificas (CADIC), C.C. 92, 9410 Ushuaia, Tierra del Fuego, Argentina \\ R. Natalie Goodall \\ Museo Acatush'un de Aves y Mam'iferos Marinos Australes, Estancia Harberton, 9410 Ushuaia, Tierra del \\ Fuego, Argentina
}

Follow this and additional works at: https://digitalcommons.unl.edu/usdeptcommercepub

Part of the Environmental Sciences Commons

\begin{abstract}
Fajardo-Mellor, Liliana; Berta, Annalisa; Brownell, Robert L. Jr.; Boy, Claudia; and Goodall, R. Natalie, "The Phylogenetic Relationships and Biogeography of True Porpoises (Mammalia: Phocoenidae) Based On Morphological Data" (2006). Publications, Agencies and Staff of the U.S. Department of Commerce. 106. https://digitalcommons.unl.edu/usdeptcommercepub/106
\end{abstract}

This Article is brought to you for free and open access by the U.S. Department of Commerce at DigitalCommons@University of Nebraska - Lincoln. It has been accepted for inclusion in Publications, Agencies and Staff of the U.S. Department of Commerce by an authorized administrator of DigitalCommons@University of Nebraska - Lincoln. 


\title{
THE PHYLOGENETIC RELATIONSHIPS AND BIOGEOGRAPHY OF TRUE PORPOISES (MAMMALIA: PHOCOENIDAE) BASED ON MORPHOLOGICAL DATA
}

\author{
LILIANA FAJARDO-MELLOR ${ }^{1}$ \\ ANNALISA BERTA \\ San Diego State University, Department of Biology, \\ 5500 Campanile Drive, San Diego, \\ California 92182, U.S.A. \\ E-mail: liliana.mellor@gmail.com \\ ROBERT L. BROWNELL JR. \\ Southwest Fisheries Science Center, \\ 1352 Lighthouse Avenue, Pacific Grove, \\ California 93950, U.S.A. \\ Claudia C. Boy \\ R. NATALIE P. GOODALL \\ Centro Austral de Investigaciones Científicas (CADIC), \\ C.C. 92, 9410 Ushuaia, Tierra del Fuego, Argentina \\ and \\ Museo Acatushún de Aves y Mamíferos Marinos Australes, \\ Estancia Harberton, 9410 Ushuaia, Tierra del Fuego, Argentina
}

\begin{abstract}
Prior studies of phylogenetic relationships among phocoenids based on morphology and molecular sequence data conflict and yield unresolved relationships among species. This study evaluates a comprehensive set of cranial, postcranial, and soft anatomical characters to infer interrelationships among extant species and several well-known fossil phocoenids, using two different methods to analyze polymorphic data: polymorphic coding and frequency step matrix. Our phylogenetic results confirmed phocoenid monophyly. The division of Phocoenidae into two subfamilies previously proposed was rejected, as well as the alliance of the two extinct genera Salumiphocaena and Piscolithax with Phocoena dioptrica and Phocoenoides dalli. Extinct phocoenids are basal to all extant species. We also examined the origin and distribution of porpoises within the context of this phylogenetic framework. Phocoenid phylogeny together with available geologic evidence suggests that the early history of phocoenids was centered in the North Pacific during the middle Miocene, with

${ }^{1}$ Current address: East Carolina University, Brody School of Medicine, Department of Anatomy and Cell Biology, 600 Moye Boulevard, Greenville, North Carolina 27834, U.S.A.
\end{abstract}


subsequent dispersal into the southern hemisphere in the middle Pliocene. A cooling period in the Pleistocene allowed dispersal of the southern ancestor of Phocoena sinus into the North Pacific (Gulf of California).

Key words: Phocoenidae, morphology, biogeography, polymorphic data, frequency step matrix.

Six extant species of Phocoenidae (porpoises) are recognized (Rice 1998). Neophocaena and Phocoenoides are monotypic whereas Phocoena includes four species. Neophocaena phocaenoides (finless porpoise) is endemic to the coastal waters of the IndoPacific, ranging from the Persian Gulf to Japan. Some workers recognize three additional species: $N$. phocaenoides in the Indian Ocean, $N$. asiaeorientalis in the Yangtze River of China, and N. sunameri in Korean and Japanese waters (Pilleri and Gihr 1972, 1975; Pilleri and Chen 1980). Others contend that such differences should be recognized at the subspecies level (Fraser 1966, Wang et al. 1989, Amano et al. 1992, Rice 1998). Recent morphometric study found significant differences in the skull size of adults of two of these forms $N$. asiaeorientalis and $N$. phocaenoides (Jefferson 2002), and ongoing molecular work may help resolve the taxonomy of this genus.

Phocoenoides dalli (Dall's porpoise) is endemic to the North Pacific and occupies the area between the U.S.-Mexico border and central Japan to the Bering and Okhotsk seas (Reeves et al. 2002). Unlike most phocoenids, Phocoenoides inhabits both oceanic and coastal waters. Rice (1998) recognized two subspecies of Phocoenoides: P. d. dalli and $P$. d. truei. These subspecies differ externally in coloration pattern; however, Jefferson (2002) suggested that the two forms are simply color morphs rather than subspecies. Recent molecular data (Escorza-Treviño et al. 2004) found significant differences between the $P . d$. dalli and the $P . d$. truei types, similar to the genetic differences observed between different populations of the $P . d$. dalli type, and suggested that $P . d$. dalli and $P . d$. truei types are forms of the same species.

The most speciose phocoenid genus Phocoena includes four species: Phocoena phocoena (harbor porpoise), Phocoena sinus (vaquita), Phocoena spinipinnis (Burmeister's porpoise), and Phocoena dioptrica (spectacled porpoise). Phocoena phocoena inhabits the coastal waters of the North Pacific and North Atlantic. Three subspecies have been recognized: $P$. phocoena phocoena in the Atlantic, $P$. phocoena vomerina in the Pacific, and $P$. phocoena relicta in the Black Sea (Rosel et al. 1995a, Read 1999). Rice (1998) rejected recognition of the Black Sea population as a subspecies and suggested that the eastern population in the North Pacific is separated from the western North Pacific population by a distributional gap in the Aleutian Islands between Shemya and Unimak.

Phocoena sinus is endemic to the northern region of the Gulf of California, having the most restricted range of any cetacean. This species is critically endangered and has an estimated population size of less than 500 individuals (Barlow et al. 1997). Phocoena spinipinnis is endemic to the coastal waters of South America, ranging from northern Peru to southern Brazil with a continuous distribution around the southern tip of Tierra del Fuego. Phocoena dioptrica has a circumpolar distribution in the Southern Ocean; however, there is very little known about the biology and distribution of this species. Similar to Phocoenoides, Phocoena dioptrica occurs in both coastal and oceanic waters.

Six species of fossil phocoenids have been described. The oldest fossil phocoenid, Salumiphocaena stocktoni, is from the late Miocene (7-11 Ma) Monterey Formation 
on the Palos Verdes peninsula, Los Angeles, California. This fossil was originally described as a delphinid of the genus Loxolithax (Wilson 1973). Based on skull morphology, Barnes (1985) re-assigned this species to a new genus of phocoenid, Salumiphocaena.

The most diverse extinct taxon, Piscolithax includes three species: Piscolithax tedfordi and Piscolithax boreios from the late Miocene (6-8 Ma) Almejas Formation, Islas Cedros, Mexico (Barnes 1984) and Piscolithax longirostris from the early Pliocene (4-5 Ma) Pisco Formation, Peru (Muizon 1984). Numataphocoena yamashitai was described from the early Pliocene (4-5 Ma) Horokaoshirarika Formation, Japan (Ichishima and Kimura 2000). Haborophocoena toyoshimai was recently described from the early Pliocene Mochikubetsu Formation in northwestern Hokkaido, Japan (Ichisima and Kimura 2005). Because of the poor preservation and the difficulty of coding characters from the literature, Numataphocoena yamashitai and Haborophocoena toyoshimai were not included in this study.

The relationship between Phocoenidae (true porpoises) and other odontocetes is contentious. Previous morphological and molecular studies (Muizon 1988; Heyning 1989, 1997; Barnes 1990; Messenger and McGuire 1998; Waddell et al. 2000; Hamilton et al. 2001) support monophyly of the Delphinoidea (including Phocoenidae, Delphinidae and Monodontidae, following Muizon [1988] and Heyning [1989]), although the relationships among delphinoids have been debated (Fig. 1). Some authors (Muizon 1988; Heyning 1989, 1997; Messenger and McGuire 1998; Hamilton et al. 2001) consider relationships among delphinoids to be unresolved (Fig. 1). Barnes (1990) proposed that Phocoenidae are more closely related to Delphinidae, and that the extinct Kentriodontidae were allied with both Delphinidae and Phocoenidae (Fig. 1D). Recent molecular data (Waddell et al. 2000, Arnason et al. 2004) support the alliance of phocoenids and monodontids as sister taxa, and delphinids as sister to that clade (Fig. 1F, I). Others have questioned the monophyly of Delphinoidea, and proposed that river dolphins are nested within that clade (Geisler and Sanders 2003, Arnason et al. 2004). The most recent comprehensive morphological study (Geisler and Sanders 2003) rejected monophyly of the Delphinoidea and proposed that the Phocoenidae and the Delphinidae share a closer alliance with the Platanistoidea (including all river dolphins: Platanista, Inia, Lipotes, and Pontoporia) rather than Monodontidae (Fig. 1G). However, there was little support (i.e., Bremer values $=1$ ) for this arrangement. Recent molecular data (Arnason et al. 2004) support paraphyly of delphinoids but rejects the monophyly of river dolphins (Geisler and Sanders 2003).

The family Phocoenidae has had a long, confusing taxonomic history. Until the end of the 19th century, phocoenids were still included in the family Delphinidae (Miller 1923, Kellogg 1928). In 1825, Gray assigned phocoenids and monodontids to the Phocoeninae; for this reason, the family group name is attributed to him. In 1885, Bravard correctly assigned all porpoises to the Phocoenidae, and this arrangement has been accepted by most later workers (Fraser and Purves 1960; Rice 1967; Gaskin et al. 1974; Brownell 1975, 1983; Barnes 1984, 1985; Heyning 1989, 1997; Rosel et al. 1995b; Geisler and Sanders 2003).

Subsequently phocoenids were recognized as a separate family with three genera: Neophocaena, Phocoena, and Phocoenoides, which have been widely accepted by later workers (Fraser and Purves 1960; Brownell 1975; Gaskin et al. 1984; Barnes 1985; Heyning 1989, 1997; Rosel et al. 1995b; Ichishima and Kimura 2000). Barnes (1985) described several osteological characters that grouped Phocoenoides and Phocoena dioptrica in the same clade and led him to assign Phocoena dioptrica to a new genus 


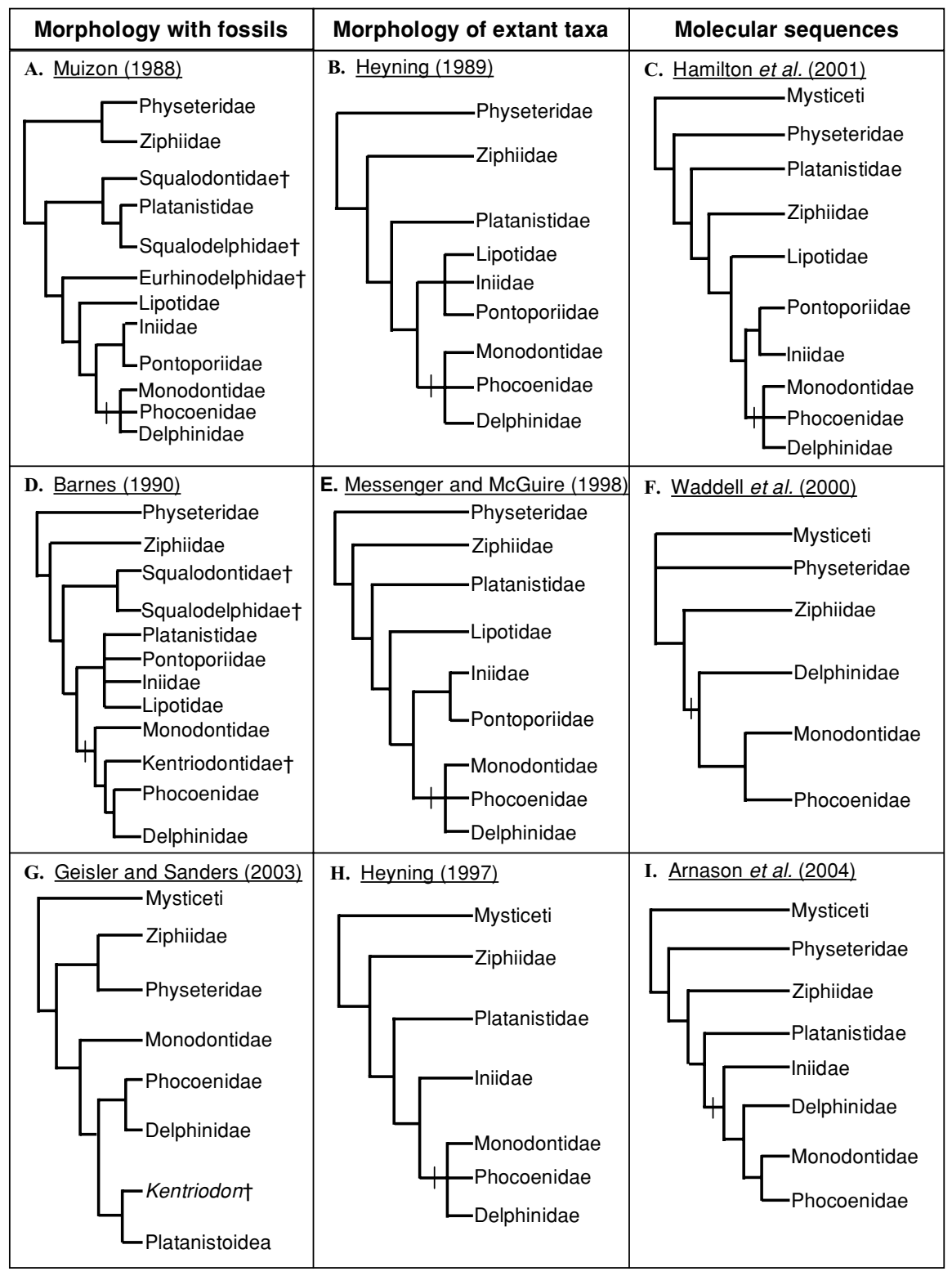

Figure 1. Previous hypotheses of odontocete relationships highlighting the position of the Delphinoidea indicated by a vertical bar, and extinct taxa indicated by a dagger.

Australophocaena. He also divided the Phocoenidae into two subfamilies: Phocoenoidinae, which included the extant Phocoenoides dalli and Australophocaena dioptrica, together with the extinct Salumiphocaena stocktoni and Piscolithax; and the subfamily Phocoeninae, comprised of the extant genera Neophocaena and Phocoena. 


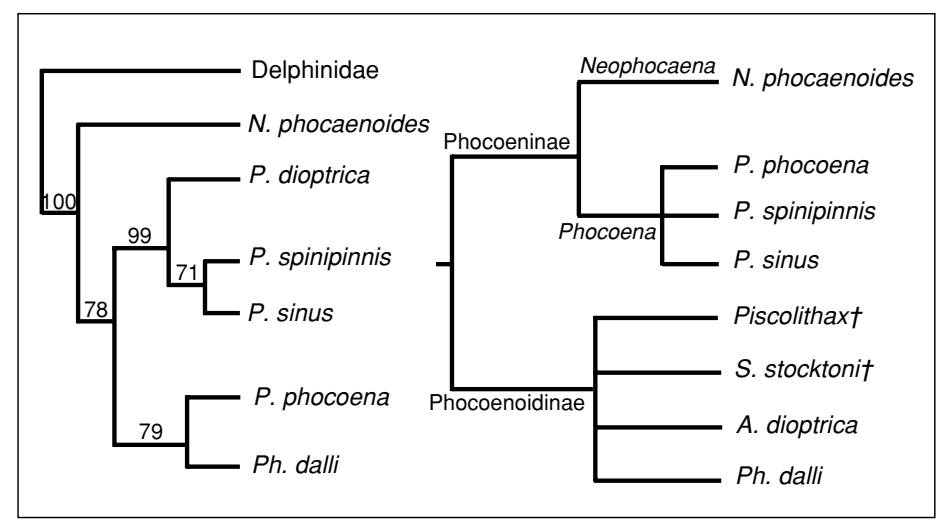

A.

B.

Figure 2. Previous hypotheses regarding phocoenid phylogeny. (A) Maximum parsimony and likelihood phylogeny of cytochrome b, gamma distance $(\alpha=2)$ (Rosel et al. 1995b). Bootstrap values are indicated. (B) Non-cladistic analysis based on morphological characters (Barnes 1985).

This classification was accepted for a decade. Rosel et al. (1995b) analyzed molecular sequence data and found no support for recognition of two subfamilies. Instead, they found that Neophocaena was basal to all phocoenids, and that the separation between northern species (Phocoena phocoena and Phocoenoides dalli) and southern species (Australophocaena dioptrica, Phocoena sinus, and Phocoena spinipinnis) was well supported. For this reason, Australophocaena dioptrica was re-assigned by Rosel et al. (1995b) to its original genus Phocoena. In addition, according to these molecular results the clade formed by $P$. phocoena and $P h$. dalli supports paraphyly of the genus Phocoena. Until now, no other phylogenetic studies have attempted to resolve the incongruence between morphological and molecular data (Fig. 2).

Previous phylogenetic studies of phocoenids have not employed rigorous systematic methods. For example, Barnes (1985) did not polarize characters, and based his morphological study mostly on selected cranial characters. As a result, he described Neophocaena phocaenoides as possessing more derived characters than any living species of Phocoena (i.e., shorter rostrum, reduced number of teeth, lack of dorsal fin, etc.). This result is contrary to the basal position of $N$. phocaenoides based on molecular data (Rosel et al. 1995b). In addition, the characters of Barnes (1985) were based on only a few specimens of each species and descriptions from the literature, and no quantitative data were collected (i.e., "larger adult body size," "longer rostrum," "smaller temporal fossae," "vertebrae more numerous"). Several workers have found some of these characters inconsistent after observing larger sample sizes. ${ }^{2}$

The most recent phylogenetic study of phocoenids (Rosel et al. 1995b) was based on mitochondrial sequence data. Their results conflict with the morphologically based study. Although Rosel et al. (1995b) included two delphinids as the outgroups, they failed to examine other possible delphinoids (e.g., Monodontidae). Their results positioned Neophocaena phocaenoides as the most basal phocoenid. They suggested that Phocoena was paraphyletic, and that Phocoenoides dalli and Phocoena phocoena represent

\footnotetext{
${ }^{2}$ Personal communication from William F. Perrin, Senior Scientist, Southwest Fisheries Science Center, 8604 La Jolla Shores Drive, La Jolla, CA 92037, 2 July 2002.
} 
the latest diverging phocoenids, a significantly different result from the morphological study (see Fig. 2). A criticism of the molecular study is the use of a single mitochondrial gene (cytochrome b) and the control region. Rokas et al. (2003) suggested that the addition of different genes leads to more accurate results, and the use of only a few genes can result in an erroneous phylogeny.

The primary objective of this study was to perform a more comprehensive morphological study of phocoenid phylogeny including extant species, better known fossil species, and more appropriate outgroups (i.e., Monodontidae, Delphinidae, Iniidae, and Pontoporiidae). We examined a comprehensive set of cranial, postcranial, and soft anatomical characters. Several phylogenetic questions were addressed: (1) Is Phocoenidae a monophyletic group? (2) Is the division of Phocoenidae into two subfamilies-Phocoeninae and Phocoenoidinae (Barnes 1985)—valid, or should all species be considered as belonging to the three major lineages proposed by Rosel et al. (1995b) (Fig. 2)? and (3) How are the fossil taxa related to each other and to extant species?

A second objective was to evaluate the evolutionary biogeography of phocoenids. We examined the origin and distribution of porpoises using physical and ecologic information (i.e., past geologic events related to opening and closing of seaways, paleo-oceanic models, changes in global temperature) in the context of a phylogenetic framework. The questions addressed include: (1) What explains the current antitropical distribution of phocoenids? (2) Did phocoenids originate in the North Pacific as hypothesized by Barnes (1985)? (3) What caused the rapid radiation of phocoenids in the middle Pliocene? and (4) Is Phocoena sinus a relict of a population of $P$. spinipinnis that crossed the equator during the Pliocene or Pleistocene and became isolated in the waters of the Gulf of California (Norris and McFarland 1958)?

\section{MATERIALS AND METHODS}

Specimens of fossil and extant phocoenids from the following institutions were examined: ITESM, Instituto Tecnológico y de Estudios Superiores de Monterrey, Guaymas, Mexico; LACM, Los Angeles County Natural History Museum, Los Angeles, California; MNHN, Museum National d'Histoire Naturelle, Paris, France; NSM, National Science Museum, Tokyo, Japan; RNP, Museo Acatushún, Tierra del Fuego, Argentina; SDNHM, San Diego Natural History Museum, San Diego, California; SDSU, San Diego State University, San Diego, California; SWFC, Southwest Fisheries Science Center, La Jolla, California; UCMP, University of California Museum of Paleontology, Berkeley, California; UCR, University of California, Riverside, California and USNM, United States National Museum of Natural History, Washington, D.C. A complete list of specimens examined is provided in Appendix 1. Morphological characters were evaluated from the cranial, postcranial, and soft anatomical regions of observed specimens and descriptions in the literature (i.e., Mead 1975, Heyning 1989, Cranford et al. 1996) and are listed in Table 1. Osteological terminology follows Rommel (1990).

Variation within species (polymorphism) was observed for some osteological characters. Several studies (Mabee and Humphries 1993, Martins and Hansen 1997, Wiens 1999) have shown that polymorphic data can be highly informative and increase accuracy; thus the exclusion of such characters is unjustified. In order to address the issue of polymorphism, two different methods for coding polymorphic data were used: polymorphic coding and frequency step matrix (Wiens 1999). 
Table 1. List of morphological characters.

1. Facial plane (Barnes 1984, Heyning 1989): $0=$ Concave, $1=$ Straight, with little inclination.

2. Premaxillary boss (Noble and Fraser 1971, Barnes 1985, Heyning 1989): $0=$ Absent, $1=$ Present.

3. Posterior projection of the right premaxilla (Muizon 1984, Barnes 1985, Heyning 1989): $0=$ Extends posterior to the narial openings, $1=$ Does not extend posterior to the narial openings, and posterior end of premaxilla is small and adjacent to the narial openings, $2=$ Does not extend beyond the narial openings, but is displaced laterally by a medial projection of the maxilla.

4. Degree of overlap of frontal by maxillary over orbit (Norris and McFarland 1958, Noble and Fraser, 1971): $0=$ Frontal bone visible at mid-length of orbit in dorsal view, $1=$ Frontal bone not visible at mid-length of orbit in dorsal view.

5. Projection of the frontal over the maxilla: $0=$ Absent or nearly absent, $1=$ Slight overhang of frontals over maxillae around the vertex of the skull, $2=$ Pronounced overhang of frontals over maxillae, extending along the lateral edges of the vertex of the skull.

6. Antorbital notch: $0=$ Well developed, $1=$ Absent or weakly developed.

7. Nasal protuberances (Muizon 1988): $0=$ Absent or very reduced, $1=$ Present.

8. Degree of telescoping (Muizon 1988): $0=$ Nasal bones do not form part of the vertex, $1=$ Nasal bones contribute to the vertex.

9. Pterygoids: $0=$ Not widely separated, $1=$ Widely separated.

10. Ventral surface of the pterygoid hamuli (Muizon 1988): $0=$ Flat or rounded, $1=$ Slightly keeled, 2 = Strongly keeled.

11. Exposure of the medial plate of pterygoid hamuli in lateral view (Noble and Fraser 1971, Muizon 1988): $0=$ Complete or broad exposure due to extreme reduction of the lateral lamina of the pterygoid hamuli, $1=$ No exposure due to a posterior extension of the lateral lamina that extends posterior to the medial plate, $2=$ Lateral lamina of pterygoid hamuli exposes the medial plate through an ovoid window in lateral view.

12. Frontal protuberance on vertex (frontal knob) (Muizon 1984): $0=A b s e n t, 1=$ Present.

13. Dorsal extension of air sinus system into frontals (Fraser and Purves 1960, Perrin and Rosel 1999): $0=$ Extension shallow, variably medium or with vermiform projection, $1=$ Extension medium, 2 = Extension deep, but narrow, $3=$ Extension deep and broad.

14. Level of the ventral margin of the foramen magnum in occipital view (Norris and McFarland 1958, Noble and Fraser 1971): $0=$ Lower margin of foramen magnum below level of lower margins of temporal fossae, $1=$ Lower margin above temporal fossae.

15. Number of teeth (Norris and McFarland 1958): $0=$ Minimum tooth counts 25-51 and maximum 33-58, $1=$ Minimum tooth counts 18-24 and maximum 26-32, $2=$ Minimum tooth counts 8-17 and maximum 20-25.

16. Posterior process of tympanic bulla (shape of bone) (Kasuya 1973, Muizon 1988): $0=$ Small, composed of spongy bone, $1=$ Large, composed of pachyostotic bone.

17. Lateral furrow of tympanic bulla (Kasuya 1973): $0=$ Well developed, $1=$ Weakly developed, $2=$ Absent

18. Fusion of cervical vertebrae (Allen, 1923, Noble and Fraser 1971): $0=$ Unfused, $1=$ Only atlas and axis fused, $2=\mathrm{C} 1-\mathrm{C} 3$ or $\mathrm{C} 1-\mathrm{C} 4$ fused, $3=\mathrm{C} 1-\mathrm{C} 5$ or $\mathrm{C} 1-\mathrm{C} 6$ fused, $4=$ C1-C7 fused.

19. Spinous process of the axis (Allen 1923, Noble and Fraser 1971): $0=$ Short, extends dorsally, $1=$ Short, extends posteriorly only to about C4, $2=$ Long, nearly contact the spinal process of $\mathrm{C} 7$.

20. Transverse foramina (vertebrarterial canal) of C4 (Allen 1923, Noble and Fraser 1971): $0=$ Complete, 1 = Incomplete or absent.

21. Transverse process of the axis (Noble and Fraser 1971): $0=$ Weakly developed or absent, $1=$ Well developed. 
Table 1. Continued.

22. Size of spinous processes of thoracic vertebrae 1-4 (Allen 1923, Noble and Fraser 1971): $0=$ Same height (except T1), $1=$ Slight increase in height from T1 to T4.

23. Inclination of the lumbar spinal processes (Allen 1923): $0=$ Spinal processes inclined posteriorly, $1=$ Spinal processes inclined anteriorly.

24. Metapophyses of the spinous processes: $0=$ Well developed, $1=$ Absent or weakly developed.

25. Acromion and coracoid processes of scapula: $0=$ Acromion longer than coracoid, $1=$ Acromion shorter than coracoid.

26. Ventral projection on the anterior border of the scapula (Noble and Fraser 1971): $0=$ Absent, $1=$ Present.

27. Supraspinous fossa (Rommel 1990): $0=$ Broad, $1=$ Narrow.

28. Olecranon process of the ulna (Howell 1927): $0=$ Absent or weakly developed, $1=$ Well developed.

29. Lower jaw (Brownell et al. 1987, Jefferson 1988): $0=$ Extends anterior to upper jaw or to same level as the upper jaw, $1=$ Upper jaw extends anterior lower jaw.

30. Prominent beak (Reeves et al. 2002): $0=$ Present, $1=$ Absent or weakly developed.

31. Apex of the flipper (Leatherwood and Reeves 1983, Brownell et al. 1987): 0 = Sharply pointed, $1=$ Rounded at tip.

32. Dorsal fin (Jefferson and Newcomer 1993, Reeves et al. 2002): $0=$ Present, large $1=$ Vertical ridge (small), $2=$ Absent.

33. Tubercles on dorsal fin (Leatherwood and Reeves 1983, Brownell et al. 1987): $0=$ Present, $1=$ Absent.

34. Sexual dimorphism (Gaskin et al. 1974, 1984; Brownell and Praderi 1984; Brownell et al. 1987; Jefferson 1990; Best and da Silva 1993; Jefferson and Newcomer 1993;

Shirakihara et al. 1993; Goodall and Schiavini 1995; Reyes and Van Waerebeek 1995; Stacey and Arnold 1999; Ralls and Mesnick 2002): $0=$ Males are larger than females, $1=$ Females are larger than males.

35. Nasofrontal sac (Heyning 1989): $0=$ Anterior sac smooth, $1=$ Anterior sac trabeculate.

36. Vestibular sac (Heyning 1989): $0=$ Not divided, $1=$ Bilaterally divided.

37. Intrinsic muscle of vestibular sac (Mead 1975): $0=$ Not in sac, $1=\mathrm{In}$ sac.

38. Vestibular sac floor (Heyning 1989): $0=$ Smooth, $1=$ Wrinkled, $2=$ Deeply folded.

39. Vestibular sac (Mead 1975, Heyning 1989): $0=$ Large, $1=$ Small.

40. Accessory sac (Schenkkan 1971, Mead 1975, Heyning 1989): $0=$ Paired and large, $1=$ Only one small or absent.

The polymorphic coding method codes polymorphic species as having two or more states. If the variable species possesses all states for a given character, the species is treated as if either state was present and therefore is uninformative when further analyzing that specific character (i.e., PAUP). If one state is more parsimonious than the other, the more parsimonious state is assigned to the variable taxon a posteriori. One of the disadvantages of using this method is that polymorphic states are not treated as synapomorphies. Another disadvantage is that this method does not take into account the frequencies of polymorphic states. For example, if you sample ten specimens of species $A$, and nine had character state 0 and only one had character state 1 , it would be coded the same way as if you observed five specimens with the ancestral state (0), and five with the derived condition (1).

The frequency step matrix employs three different ways of coding frequency data, one of which was used in this study and is described below (see Wiens 1999, for additional methods). Frequency data, unlike other polymorphic methods, take into account the frequency of traits within a given species and weights changes between 
states based on differences in frequencies (Wiens 1999). The frequency step matrix, assigns different character states for each frequency, resulting in a unique matrix with a set of frequencies. The cost of transition between character states is calculated by finding the Manhattan distances (Swofford and Berlocher 1987) between the frequencies. For instance, it is more expensive to transition from $0 \%$ to $100 \%$ than to go from $50 \%$ to $100 \%$.

The polymorphic coding method employed the program MacClade 4.0 (Maddison and Maddison 2000) and the frequency step matrix used Manhattan distances (Swofford and Berlocher 1987, Wiens 1999) for character coding. Both methods were then analyzed using PAUP 4.0b10 (Swofford 2000). All characters were treated as unordered and unweighted using heuristic search if the number of taxa was more than 12 (i.e., including fossils and extant taxa), or exhaustive search when the total number of taxa was less than 12 (i.e., extant taxa only). In the case of more than one most parsimonious tree, a strict consensus tree was calculated and the non-parametric bootstrap support values were estimated with 1,000 replicates (Felsenstein 1985).

The outgroup comparison method (Watrous and Wheeler 1981, Maddison et al. 1984) was used to determine character polarity, which estimates the ancestral state at the outgroup node or the condition exhibited by the hypothetical ancestor. In the case of an equivocal state of the hypothetical ancestor, the character was left unpolarized. Exemplars of Delphinidae (true dolphins) and Monodontidae (beluga and the narwhal), Iniidae (Amazon river dolphins) and Pontoporiidae (La Plata dolphins) were selected. Phocoenidae is sister to Delphinidae and Monodontidae that together form the Delphinoidea (Muizon 1984, Heyning 1989). Two families of river dolphins, Iniidae and Pontoporiidae, have been hypothesized as sister taxa to delphinoids (Muizon 1988; Heyning 1989, 1997; Barnes 1990; Messenger and McGuire 1998; Cassens et al. 2000; Hamilton et al. 2001); however, the relationships among these taxa are unresolved and the monophyly of delphinoids is uncertain (Geisler and Sanders 2003). Inia geoffrensis and Pontoporia blainvillei putative sister taxa of delphinoids (Muizon 1988, Messenger and McGuire 1998, Hamilton et al. 2001) were both included in the study. One of the two extant monodontids, Delphinapterus leucas (beluga whale) was included. Delphinidae, the most diverse family of cetaceans includes at least 33 species. In the most recent comprehensive phylogenetic study of delphinids, the entire cytochrome b sequence of virtually all recognized species and four outgroups (two phocoenids and the two extant monodontids) was analyzed (LeDuc et al. 1999). Results of this study support monophyly of three distinct delphinid clades: Globicephalinae, Delphininae, and Lissodelphininae with very little resolution. For this reason, we selected one species from two of the major delphinid clades and a single species exclusive to these clades: Orcaella brevirostris (Irrawaddy dolphin), Tursiops truncatus (bottlenose dolphin-Delphininae), and Lissodelphis borealis (northern right whale dolphin-Lissodelphininae).

\section{PHYLOGENETIC ANALYSIS}

Separate analyses of different partitions of the morphological data were performed to identify and compare the phylogenetic signal of partitioned data, and to address the importance of including postcranial and soft anatomical characters in morphological studies (Appendices 2 and 3). First, all taxa were included to determine the relationships among fossils and their extant relatives, and to compare with the previous morphological study (Barnes 1985). Second, a partitioned analysis of cranial 
characters for extant taxa was performed to compare with the previous morphological study in which mainly cranial characters were used, and to test whether the addition of characters from the postcranial and soft anatomical regions would help resolve relationships. Third, analysis of extant taxa including all characters was done to compare results with the previous molecular study (Rosel et al. 1995b) and with the results of the cranial data set. The phylogenies obtained using both the polymorphic coding method and the frequency step matrix are discussed.

In the first analysis, four of the better-known fossil phocoenids (i.e., Piscolithax boreios, Piscolithax tedfordi, Piscolithax longirostris, and Salumiphocaena stocktoni) and all six extant species were included. The phylogenies based both on polymorphic coding and frequency step matrix methods (Fig. 3A, B) include only cranial characters because of the large amount of missing data for the fossils (i.e., few postcranial and no soft anatomical data) and the lack of resolution when all characters are included. The polymorphic coding method failed to support monophyly of phocoenids (i.e., Inia geoffrensis and Pontoporia blainvillei are nested within phocoenids) and was unable to resolve most relationships within phocoenids (Fig. 3A). The extinct genus Piscolithax appears monophyletic, but support is weak ( $<70 \%$ bootstrap). All extinct taxa are basal to extant phocoenids; however, that clade is not well supported. Among extant phocoenids, there is no strong support ( $<70 \%$ bootstrap) among $N$. phocaenoides, $P$. sinus, and $P$. spinipinnis, and the only clade that was well supported is Phocoena dioptrica + Phocoena phocoena + Phocoenoides dalli (Fig. 3A). Based on the lack of resolution and the low bootstrap support for most of the clades, very little can be inferred from this phylogenetic hypothesis.

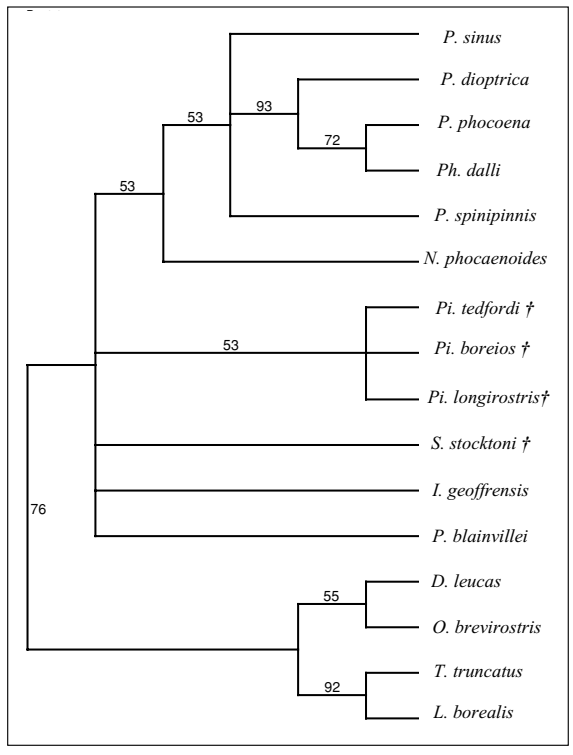

A.

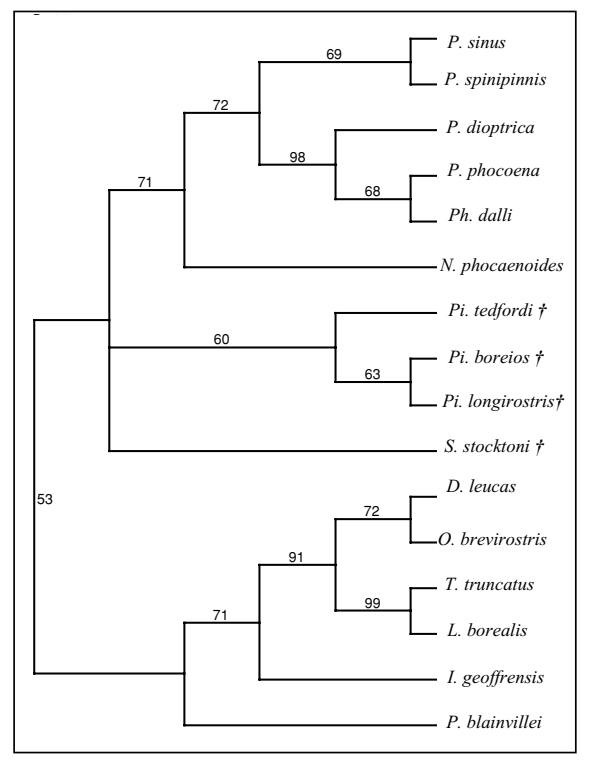

B.

Figure 3. Phylogeny of extant and fossil phocoenids using cranial characters only. (A) Polymorphic method. Strict consensus of 9 MP trees, tree length 45, CI $=0.622$. Numbers represent bootstrap values. (B) Frequency step matrix method. Strict consensus of 9 MP trees, tree length $477.10, \mathrm{CI}=0.607$. Numbers represent bootstrap values. 
Using precise information on the frequencies for each trait (i.e., frequency step matrix) provided greater resolution between extinct and extant taxa. Although phocoenids appear monophyletic in this analysis, this result is weakly supported (Fig. 3B). Based on these results, extinct taxa are basal to extant phocoenids. Neophocaena phocaenoides is the most basal extant phocoenid as previously suggested by Gaskin (1976) and Rosel et al. (1995b). Later diverging taxa are divided into two clades: P. spinipin$n i s+P$. sinus, and $P$. phocoena $+P$. dioptrica $+P h$. dalli. Based on cranial data, the two northern species $P$. phocoena and $P h$. dalli are sister taxa as suggested by a previous molecular study (Rosel et al. 1995b) and supports the paraphyly of Phocoena; however, the bootstrap support for that clade is weak ( $<70 \%$ bootstrap).

Another run of the data excluded fossil taxa and inferred relationships among extant taxa based on cranial characters only (Fig. 4A, B). The polymorphic coding method found good support for a monophyletic Phocoenidae, as well as for the basal position of Neophocaena phocaenoides. The clade formed by $P$. dioptrica, $P$. phocoena, and $P h$. dalli is still well supported, and the relationship of the two northern species as sister taxa is better supported after removing the fossils. The only relationship based on cranial data not supported by the polymorphic coding method is that between $P$. sinus and $P$. spinipinnis (Fig. 4A). Similar results were obtained using the frequency step matrix method except that the relationship between $P$. phocoena and $P h$. dalli was not well supported, but all other relationships within phocoenids were well supported, including the monophyly of the group and the paraphyly of Phocoena (Fig. 4B). Based on the results using cranial data only, there is no support for the division of the family into two subfamilies as proposed by Barnes (1985).

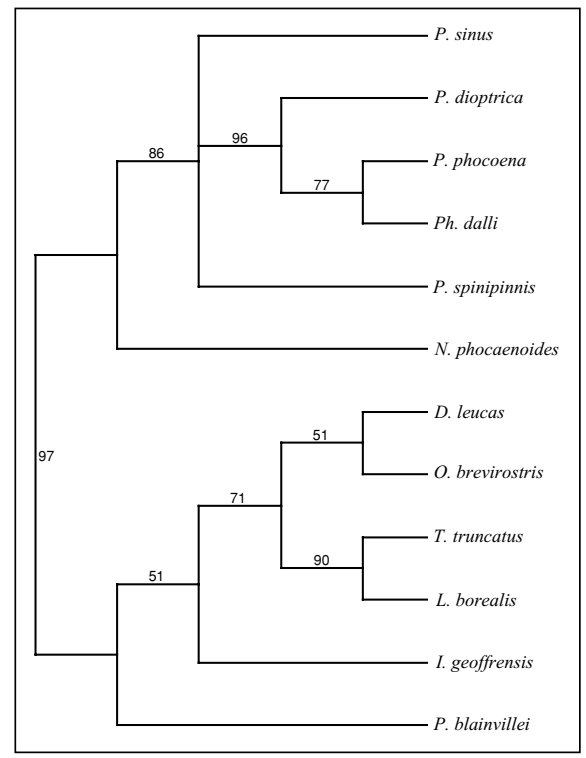

A.

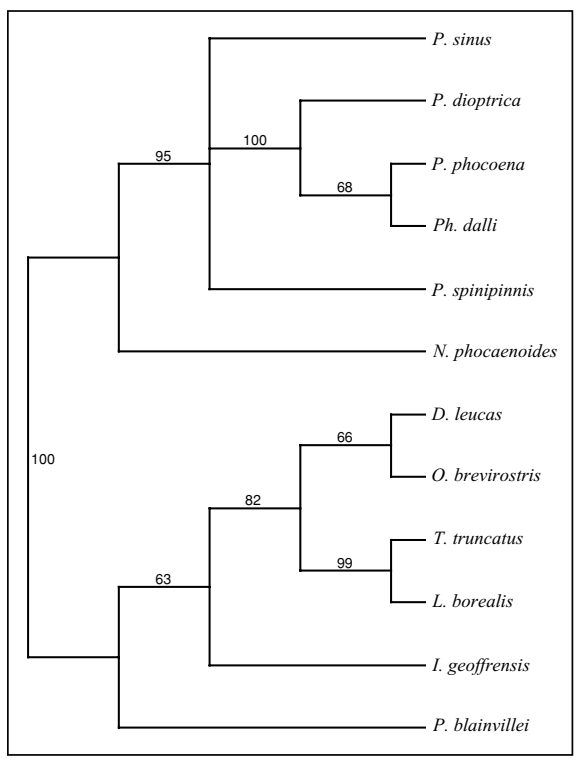

B.

Figure 4. Phylogeny of extant phocoenids including cranial characters only using (A) polymorphic coding method. Strict consensus of $2 \mathrm{MP}$ trees, tree length $37, \mathrm{CI}=0.73$. Numbers represent bootstrap values. (B) Frequency step matrix method. 2 MP tree, tree length 397.10, CI $=0.726$. Numbers represent bootstrap values. 


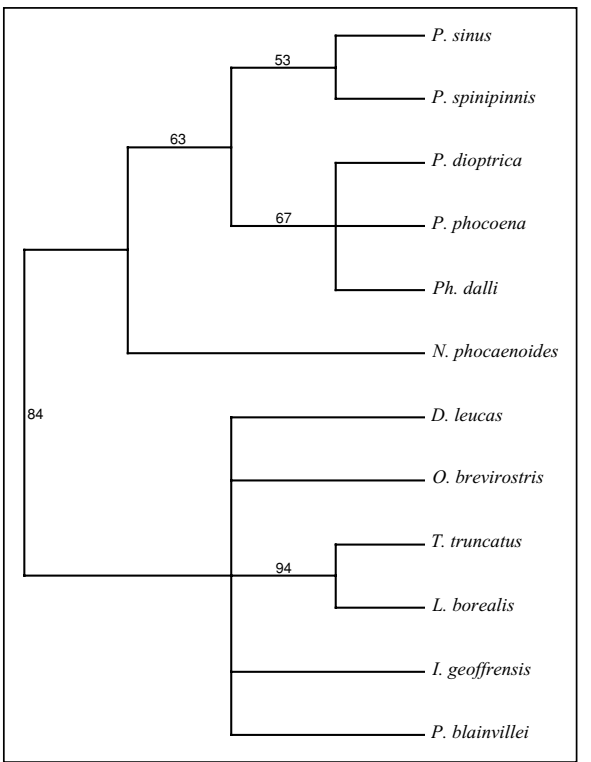

A.

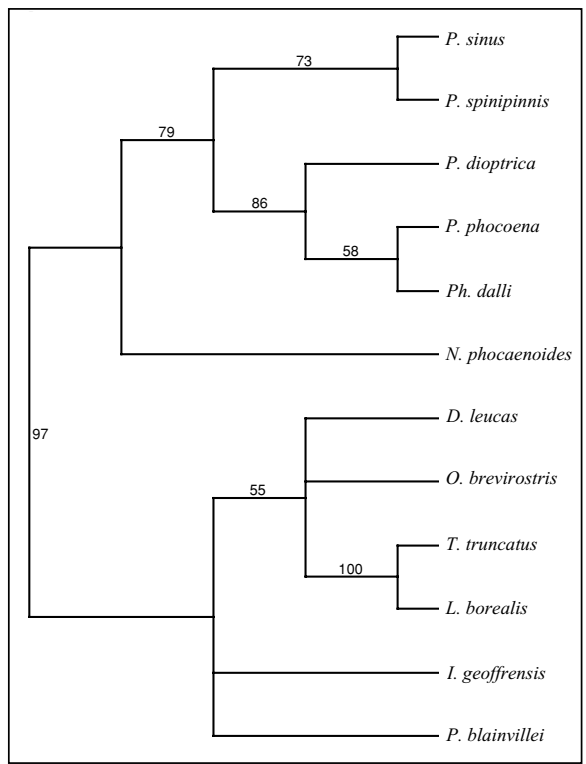

B.

Figure 5. Phylogeny of extant phocoenids including all characters using (A) polymorphic coding method. $1 \mathrm{MP}$ tree, tree length $88, \mathrm{CI}=0.591$. Numbers represent bootstrap values. (B) Frequency step matrix method. $1 \mathrm{MP}$ tree, tree length 932.80, CI $=0.577$. Numbers represent bootstrap values.

The final analysis included characters from the cranial, postcranial, and soft anatomical regions. The polymorphic coding method was unable to resolve relationships between $P$. dioptrica, $P$. phocoena, and $P h$. dalli, and none of the clades within phocoenids were well supported (Fig. 5A). The frequency step matrix method provided better resolution and support when compared to the polymorphic method, and the only node with weak support is the alliance of $P$. phocoena and $P h$. dalli (Fig. 5B).

Barnes (1985) described fossil and extant phocoenids as sharing the following "unique suite of derived cranial characters": presence of a premaxillary prominence on the posterior end of each premaxilla, small posterior termination of the premaxilla that does not reach the nasal bone, palatine bones that are relatively widely exposed on the palate, separating the hamular processes of the pterygoids, branch of the preorbital lobe of the air sinus system that extends from the orbit dorsally into a recess that lies between the frontal bone and the facial portion of the maxillary bone on either side of the skull, and an asymmetrical cranial vertex slightly offset to the left side. When the distribution of these putative synapomorphies is considered among outgroup taxa, only the premaxillary prominence was confirmed as a synapomorphy of phocoenids.

In this study, the monophyly of extant and extinct phocoenids was not well supported by either polymorphic coding or frequency step matrix methods (Fig. 3A, B). These results could be due to the small sample size of the fossils (only one specimen for each recognized species), missing data due to incomplete material, and/or coding from the literature (i.e., Salumiphocaena stocktoni and Piscolithax longirostris) 
(Wilson 1973, Muizon 1984). The only unique character that unites fossil and extant phocoenids is the posterior projection of the right premaxilla (Table 1, character 3), which is small and adjacent to the narial openings and does not extend posterior to the narial openings as it does in delphinids, Inia and Pontoporia. Characters that are present in all phocoenids but may also occur in other taxa (i.e., either as homoplasies or their homology is in question) are considered equivocal synapomorphies and require further study. Equivocal synapomorphies for fossil and extant phocoenids are: presence of a premaxillary boss on the posterior end of each premaxilla (Table 1, character 2), nasal bones located in the ascending part of the skull that do not form part of the vertex (Table 1, character 8 ), pterygoid hamuli that are widely separated by the palatine bones and/or the vomer (Table 1, character 9), and large posterior process of the tympanic bone composed of pachyostotic bone (Table 1, character 16).

Although the monophyly of phocoenids was not well supported when extinct taxa were included, it was well supported based on extant taxa (Figs. 4, 5). In addition to the reduced posterior end of the premaxillae, synapomorphies that support monophyly of extant phocoenids are: fusion of three or more cervical vertebrae (Table 1, character 18), trabeculate anterior sac (Table 1, character 35), vestibular sac enclosed by an intrinsic muscle (Table 1, character 37), and vestibular sacs with deep transverse folds (Table 1, character 38).

Equivocal synapomorphies of extant phocoenids include: presence of a frontal protuberance on the vertex (Table 1, character 12), weakly developed lateral furrow of the tympanic bulla (Table 1, character 17), spinous processes of thoracic vertebrae 1-4 that are similar in height (Table 1, character 22), short beak (Table 1, character 30), small and bilaterally divided vestibular sacs (Table 1, character 36), and accessory sac absent or only one small sac present (Table 1, character 40).

Neophocaena phocaenoides differs from other extant phocoenids in having a welldeveloped antorbital notch (Table 1, character 6), relatively flat nasal bones (Table 1, character 7), shallow dorsal extension of the air sinus system into the frontals (Table 1, character 13), weakly developed olecranon process of the ulna (Table 1, character 28), and a vertical ridge instead of a dorsal fin (Table 1, character 32). The clade formed by $P$. sinus and $P$. spinipinnis is supported by the following unique characters: frontal bone visible at mid-length of orbit in dorsal view (Table 1, character 4), and complete transverse foramina in the fourth cervical vertebra (Table 1, character 20). The clade comprised of $P$. dioptrica, $P$. phocoena, and $P h$. dalli is supported by the following characters: small exposure of the medial plate through an ovoid window of the lateral lamina of the pterygoid hamuli (Table 1, character 11), fusion of 5 or more cervical vertebrae (Table 1, character 18), and long spinous process of the atlas that nearly contacts the spinal process of the last cervical vertebra (Table 1, character 19). Lastly, $P$. phocoena and $P h$. dalli share three unique characters: tooth counts that range between 18-24 and 26-32 (Table 1, character 15), well-developed transverse process of the axis (Table 1, character 21), and ventral projection on the anterior border of the scapula (Table 1 , character 26).

\section{DISCUSSION}

Similar to the previous molecular study (Rosel et al. 1995b), morphological data from this study supports Neophocaena phocaenoides as the most basal extant phocoenid, and the division of later diverging taxa into two separate clades; however, the relationships among these clades differ between this study and the molecular study 
(Rosel et al. 1995b). Molecular data supports the relationship of $P$. dioptrica as sister taxon to $P$. sinus and $P$. spinipinnis, but based on this study, $P$. dioptrica is more closely related to the two northern species $P h$. dalli and $P$. phocoena. Constraining the molecular topology to the morphological data set, results in a tree that is five steps longer (i.e., tree length of constrained tree $=93$ and tree length of MP morphological tree $=$ 88). Similar to the molecular study (Rosel $e t$ al. 1995b), the two northern species $P$. phocoena and $P h$. dalli are sister taxa; however, the bootstrap support for this clade is below $70 \%$.

The partitioned analysis of cranial characters using both the polymorphic coding and frequency step matrix methods were unable to resolve relationships between $P$. sinus, $P$. spinipinnis and the clade formed by $P$. dioptrica, $P$. phocoena, and $P h$. dalli (Fig. 4). The addition of postcranial and the soft anatomical characters resolved this polytomy by grouping $P$. sinus and $P$. spinipinnis as sister taxa, in agreement with the molecular study (Rosel et al. 1995b). The polymorphic coding method decreased the resolution and bootstrap support after the addition of postcranial and soft anatomical characters, which could be a result of the increase in number of polymorphic characters from the postcranial region (Fig. 5A). By contrast, the frequency step matrix method increased both the resolution and bootstrap support for all clades after the addition of more frequency data (Fig. 5B). In any case, additional characters from the postcranial and soft anatomical regions help resolve relationships that were not supported by the partitioned analysis of the cranial region. For example, Buchholtz and Schur (2004) concluded that vertebral anatomy provided a previously little-used source of characters that contributed to the resolution of phylogenetic relationships within Delphinidae. As this study has shown, phylogenetic analyses of morphological data should include comprehensive data sets (i.e., cranial, postcranial, and soft anatomical data) and both living and fossil taxa (Wiens 2004). In addition to comparison of the morphological and molecular sequence data presented herein, the next step is a "total evidence" approach that integrates morphological and molecular data among living and extinct taxa and offers the potential benefit of increased phylogenetic resolution (O'Leary et al. 2004).

Including fossil phocoenids in the phylogeny is especially important when tracing the evolutionary history of character transitions because of their basal phylogenetic position. For example, when the total number of teeth (Table 1, character 15) in phocoenids is mapped onto the phylogeny of extant taxa, the hypothesized ancestral state for the family is a minimum tooth count of 8-17 and maximum of 20-25 (Fig. 6A). When fossils are included, the basal position of the extinct taxa defines the ancestral condition of the family as having more teeth, with a minimum tooth count of 25-51 and a maximum count of 33-58 (Fig. 6B).

\section{EVOLUTIONARY BIOGEOGRAPHY}

Phocoenids have an antitropical distribution. Other marine organismal groups with antitropical distributions include giant kelps (Macrocystis integrifolia and Macrocystis pyrifera), fur seals (Arctocephalus), elephant seals (Mirounga), crustaceans (Lithodes, Cancer, Taliepus, Hemigrapsus, and Cyclograpsus), gastropods (Tegula, Thais and Acanthina), bivalves (Protothaca and Mytilus), and several species of fishes (Dall 1909, Ekman 1953, Garth 1957, Soot-Ryen 1959, Gaskin 1976, King 1983, Hickman and McLean 1990, Lindberg 1991, Deméré et al. 2003). Most marine species that have antitropical distributions live in the eastern Pacific, and for this reason, most 


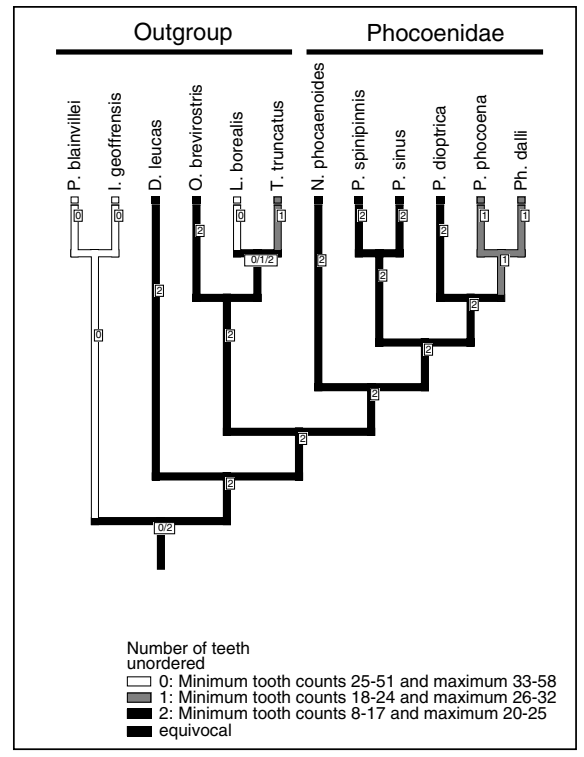

A.

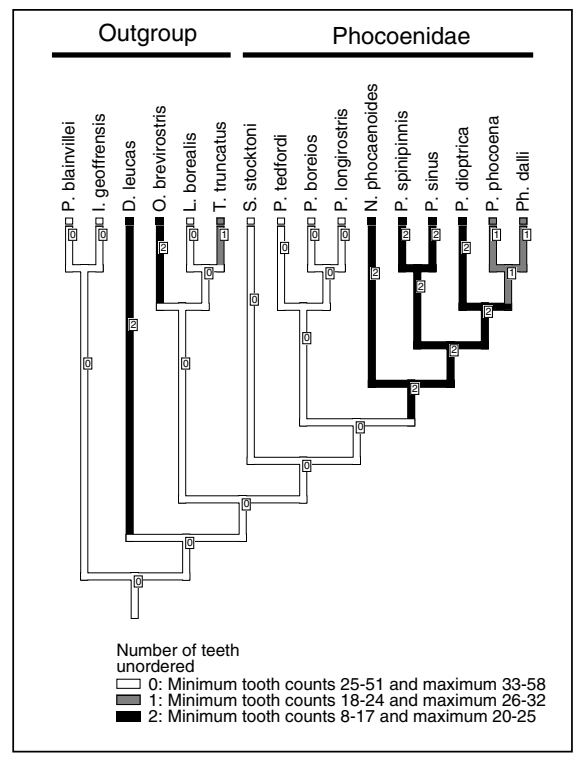

B.

Figure 6. Number of teeth (character 15) mapped onto morphology based tree in this study. (A) Extant taxa only, and (B) Extant and extinct taxa.

studies of antitropical distributions focus on geological events in this ocean basin. We discuss below the most influential geologic events argued to have resulted in the antitropical distribution of several marine organisms, and correlate these events with the inferred phylogeny of phocoenids and the estimated molecular divergence rates from the previous molecular study (Rosel et al. 1995b).

Jacobs et al. (2004) proposed that most of the marine diversity in the eastern North Pacific Ocean developed as the result of an upwelling regime that began during the middle Miocene initiated by glaciation of Antarctica (12-15 Ma). Cooling below the thermocline of the Southern Ocean adjacent to Antarctica produced upwelling in the North Pacific creating nutrient-rich waters. Because of this ideal condition in the North Pacific, it is very likely that marine organisms in the Pacific that diverged during the middle Miocene, originated in this region (Jacobs et al. 2004, Lindberg ${ }^{3}$ ).

A second major event occurred during the Pliocene (5-2 Ma). After the optimal conditions of upwelling during the Miocene, there was a tremendous reduction in upwelling during the Pliocene (Jacobs et al. 2004) and the global climate was unusually warm (Knies et al. 2002). An important geologic event that influenced ocean conditions in the eastern North Pacific is the closure of the Panamic portal by $3.1 \mathrm{Ma}$ (Lindberg 1991, Jacobs et al. 2004). This closure altered the tropical current patterns and the water temperatures in the coastal region. According to Weaver (1990), closure of the Panamic portal caused the California Current to flow closer to the equator,

\footnotetext{
${ }^{3}$ Personal communication from David R. Lindberg, Professor and Chair, Department of Integrative Biology, University of California, 3060 Valley Life Science Building, Berkeley, CA 94720-3140, 22 April 2004 .
} 
allowing species to disperse from the northern into the southern hemisphere. These favorable current conditions provide evidence to support antitropical distribution patterns during the Pliocene. In addition, Lindberg (1991) observed that $90 \%$ of the taxa he studied migrated from the northern into the southern hemisphere during the Pliocene, and only $10 \%$ migrated from south to north. Correlation of geologic and paleontological events suggested that antitropical distribution was a product of biotic interchange between the two hemispheres, rather than vicariance (Lindberg 1991).

The final geologic event that contributed to antitropical distributions in marine organisms was the initiation of the northern hemisphere glaciation, which began in the late Pliocene $(\sim 2.5 \mathrm{Ma})$ and continued throughout the Pleistocene $(2-1 \mathrm{Ma})$, in which tropical water temperatures dropped allowing species to cross the warm equatorial barrier and disperse into the northern and southern hemispheres (Hubbs 1952, Lindberg 1991). Some authors believe that cooling alone cannot be responsible for dispersal between the two hemispheres, and additional factors contributed to the interchange during the Pleistocene, such as compression of the temperate and tropical zones, changes in upwelling intensity, storm tracks, and sea-level changes (Lindberg 1991). The biotic interchange between the southern and the northern hemisphere during the Pleistocene was nearly symmetrical, with $40 \%$ of the taxa migrating from north to south and 60\% from south to north (Lindberg 1991).

There is an interesting correlation between these three main geologic events during the Miocene, Pliocene, and Pleistocene and phocoenid phylogeny. Estimated molecular divergence rates from a previous molecular study (Rosel et al. 1995b) are mapped on the congruent nodes between this study and the previous molecular study to provide more accurate times of divergence (Fig. 7). According to the estimated molecular divergence rates, phocoenids diverged from other odontocetes 12-16 Ma (Rosel et al. 1995 b). This date roughly corresponds with the fossil record (Fig. 7, node A). The most basal extant phocoenid, Neophocaena phocaenoides, is endemic to the Indo-Pacific. By considering only extant taxa, one could argue that phocoenids originated in this ocean basin. When fossils are included, the most basal phocoenids are the extinct taxa Piscolithax boreios and Piscolithax tedfordi from Isla Cedros, Baja California, Mexico; Salumiphocaena stocktoni from Palos Verdes, California; and Piscolithax longirostris from Sacaco, Peru. The most parsimonious explanation suggests an eastern North Pacific origin of phocoenids during the Miocene, with a single migration to the southern hemisphere (Piscolithax longirostris), which correlates with the North Pacific origin of other marine organisms (Jacobs et al. 2004), and suggests antitropical speciation in the late Miocene.

Rosel et al. (1995b) suggest a rapid radiation during the Pliocene (2-3 Ma) of all other extant phocoenids, excluding Neophocaena phocaenoides (Fig. 7, node B). As previous biogeographic studies suggested, the closing of the Isthmus of Panama (3.1 Ma) and other factors resulting from this geologic event (i.e., change in tropical currents and water temperature), allowed northern species to disperse into the southern hemisphere. It is probable that during this time, a northern common ancestor dispersed to the southern hemisphere resulting in speciation of the southern species Phocoena dioptrica and Phocoena spinipinnis. Even though this is not the most parsimonious explanation, there is evidence from other antitropical marine taxa and geologic events to support this hypothesis of a north to south migration during the middle Pliocene (Lindberg 1991).

The final event that contributed to the antitropical distribution of phocoenids is cooling during the Pleistocene that allowed species to cross the equatorial barrier 


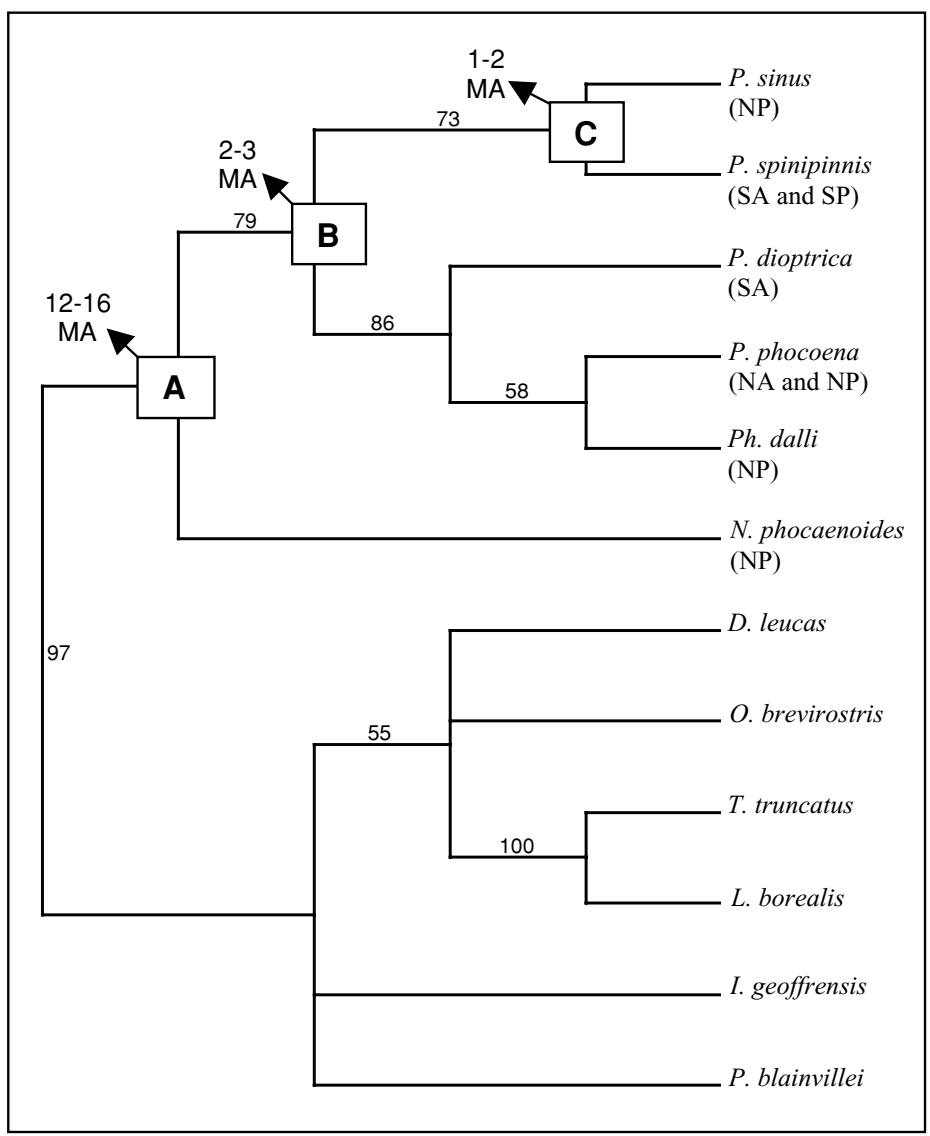

Figure 7. Phocoenid phylogeny and biogeography based on this study. Numbers at the nodes correspond to the estimated molecular divergence rates from previous molecular data (Rosel et al. 1995b). Values are mapped for all congruent nodes. NP $=$ North Pacific, $\mathrm{SP}=$ South Pacific, NA = North Atlantic, and SA = South Atlantic.

and disperse into a different hemisphere. According to Hubbs (1952), the Humboldt Current in the South Pacific converged with the Northern Current creating a corridor between the southern and northern hemispheres, which facilitated the dispersal of marine organisms. Norris and McFarland (1958) suggested that the southern ancestor of Phocoena sinus crossed the equator during the Pleistocene, and became trapped in the Gulf of California. This hypothesis was later supported by a morphologic study of the skulls of Phocoena phocoena, Phocoena sinus, and Phocoena spinipinnis (Noble and Fraser 1971), molecular data (Rosel et al. 1995b), and is now supported by this morphological study. The estimated rate of divergence for this node based on previous molecular data is 1-2 Ma (Fig. 7, node C). A similar event likely resulted in speciation of the two northern species Phocoena phocoena and Phocoenoides dalli, whereby a southern ancestor crossed the equatorial barrier and speciated into these two taxa. However, there is no molecular divergence rate to support the timing of this event. 
In summary, there seems to be sufficient geological data and examples of other marine organisms to explain the antitropical distribution of phocoenids in three steps. First, the divergence of phocoenids from other delphinoids occurred in response to optimal upwelling conditions in the eastern North Pacific that resulted from the continued glaciation in Antarctica during the middle Miocene (12-15 Ma). Secondly, dispersal into the southern hemisphere after the closing of the Panamic portal (3.1 Ma) changed the current patterns and tropical temperatures in the North Pacific, allowing species to cross the warm equatorial barriers. Thirdly, a cooling period during the Pleistocene allowed a southern common ancestor to disperse into the northern hemisphere and speciate into the northern species. Additional molecular data with divergence rates for all the nodes would be useful to confirm or reject this biogeographic pattern.

\section{Conclusions}

This study provides new phylogenetic and biogeographic hypotheses for extinct and extant members of the family Phocoenidae. A comprehensive data set of 17 cranial, 11 postcranial, and 12 soft anatomical characters for extant taxa and four of the five better known fossil phocoenids, provide different results from those previously proposed. The division of the family into two subfamilies (Barnes 1985) was rejected, as well as the alliance of the two extinct genera with $P$. dioptrica and $P h$. dalli. The extinct taxa are basal to all extant phocoenids, with Salumiphocaena stocktoni identified as the most basal phocoenid and a later diverging clade that includes Piscolithax; however, there is weak support for this arrangement (bootstrap $<70$ ). Because of the basal position of extinct taxa, inclusion of fossils in the phylogeny is essential when tracing the evolution of characters.

Results from two different methods of coding polymorphic data support the position of Neophocaena phocaenoides as the most basal extant phocoenid. Also confirmed is the division of other extant phocoenids into two clades; Phocoena sinus + Phocoena spinipinnis, and Phocoena phocoena + Phocoenoides dalli + Phocoena dioptrica. These results are similar to those previously proposed (Rosel et al. 1995b) based on molecular data. The only incongruence between the two studies is the position of Phocoena dioptrica, which according to the molecular study (Rosel et al. 1995b) is more closely related to Phocoena sinus and Phocoena spinipinnis, whereas in this study it is more closely related to Phocoena phocoena and Phocoenoides dalli. Further phylogenetic analyses that include other mitochondrial and nuclear genes, and a combined analysis of morphological and molecular data may help better resolve relationships among phocoenids.

The phylogeny played a critical role in providing a framework for constructing biogeographic hypotheses. According to this study, three main geologic events contributed to the antitropical distribution of phocoenids. First, glaciation of Antarctica during the middle Miocene (12-15 Ma) produced upwelling in the North Pacific that promoted the speciation of phocoenids. The closure of the Isthmus of Panama (3.1 Ma) in the middle Pliocene altered oceanic current patterns and temperatures in the North Pacific, allowing northern species to disperse into the southern hemisphere (Weaver 1990, Lindberg 1991, Jacobs et al. 2004). Lastly, a cooling period in the South Pacific during the Pleistocene (1-2 Ma) allowed southern species to cross the equator and disperse into the northern hemisphere.

The addition of fossils to the phylogeny provides another example of an antitropical clade within the family. When fossil taxa are excluded, there are two distinct clades 
in which southern species are closely related to northern species. Inclusion of extinct taxa provides an additional example of an extinct clade in which a southern species (i.e., Piscolithax longirostris) is closely related to three northern species (Piscolithax boreios, Piscolithax tedfordi, and Salumiphocaena stocktoni); however, the timing of this divergence is unknown.

\section{ACKNOWLEDGMENTS}

We would like to thank the following individuals who allowed us collection access: Jorge Torres (ITESM, Guaymas, Mexico); Larry Barnes, John Heyning, and Dave Janiger (LACM, Los Angeles, CA); Jim Mead and Charlie Potter (USNM, Washington, D.C.); Tadasu Yamada (NSM, Tokyo, Japan); Tom Deméré and Phil Unitt (SDNHM, San Diego, CA). We would also like to acknowledge Bill Perrin for all his helpful comments and for providing unpublished character descriptions for our review. Special thanks to Larry G. Barnes, Jorge Torre, J. David Archibald, R.H. Defran, Tod Reeder, David Lindberg, John Wiens, and Thomas Jefferson for their valuable comments and suggestions throughout this study, and to the personnel of the Museo Acatushún during my stay in Tierra del Fuego.

We would also like to acknowledge funding sources for this study including Sigma Xi, Phi Beta Delta Scholarship, San Diego State University International Travel Scholarship, SDSU Evolutionary Biology Student Fund to L. Fajardo-Mellor. The collection of phocoenid specimens in southernmost South America was largely supported by continuing grants from the Committee for Research and Exploration of the National Geographic Society to RNP. Thanks are given to estancias in Tierra del Fuego for logistic support, especially Estancia San Martin for permitting RNP to maintain a field camp on its property. NSF funding (DEB 0212248) to A. Berta contributed indirectly to completion of this project.

This research was completed in partial fulfillment of a M.S. degree to L. Fajardo-Mellor in the Department of Biology at San Diego State University, CA.

\section{LITERATURE CITED}

Allen, G. M. 1923. The black finless porpoise, Neomeris. Bulletin of the Museum of Comparative Zoology, Harvard College 65(7):233-256.

AMANO, M., N. MiYAZAKI AND K. KUREHA. 1992. A morphological comparison of skulls of the finless porpoise Neophocaena phocaenoides from the Indian Ocean, Yangtze River and Japanese waters. Journal of the Mammalogical Society of Japan 17:59-69.

ARnason, U., A. GUlLberg AND A. JANKe. 2004. Mitogenomic analyses provide new insights into cetacean origin and evolution. Gene 333:27-34.

Barlow, J., T. Gerrodette and G. Silber. 1997. First estimates of Vaquita abundance. Marine Mammal Science 13(1):44-58.

BARNeS, L. G. 1984. Fossil odontocetes (Mammalia: Cetacea) from the Almejas Formation, Isla Cedros, Mexico. PaleoBios 42:1-46.

BARNES, L. G. 1985. Evolution, taxonomy and antitropical distribution of the porpoises (Phocoenidae, Mammalia). Marine Mammal Science 1:149-165.

BARNES, L. G. 1990. The fossil record and evolutionary relationship of the genus Tursiops. Pages 3-26 in S. Leatherwood and R. Reeves, eds. The bottlenose dolphin. Academic Press, San Diego, CA.

BeST, R. C., AND V. M. F. DA SILVA. 1993. Inia geoffrensis. Mammalian Species 426:1-8.

BRAVARD, A. 1885. Monografía de los terrenos marinos Terciarios de las cercanías del Paraná. Anales del Museo Nacional de Historia Natural, Buenos Aires 1(3):45-94.

Brownell, R. L. JR. 1975. Phocoena dioptrica. Mammalian Species 66:1-3.

BrownelL, R. L. JR. 1983. Phocoena sinus. Mammalian Species 198:1-3.

Brownell, R. L. JR., AND R. Praderi. 1984. Phocoena spinipinnis. Mammalian Species 217: $1-4$. 
Brownell, R. L. JR., L. T. Findley, O. Vidal, A. Robles And S. MANZANilla. 1987. External morphology and pigmentation of the Vaquita, Phocoena sinus (Cetacea: Mammalia). Marine Mammal Science 3(1):22-30.

BuchHoltz, E. A., AND S. A. SCHur. 2004. Vertebral osteology in Delphinidae (Cetacea). Zoological Journal of the Linnean Society 140:383-401.

Cassens, I., S. Vicario, V. G. Waddell, H. Balchowsky, D. V. Belle, W. Ding, C. Fan, R. S. Lal Mohan, P. C. Simoes-Lopes, R. Bastida, A. Meyer, M. J. Stanhope AND M. C. MiLinKOviTCH. 2000. Independent adaptation to riverine habitats allowed survival of ancient cetacean lineages. Proceedings of the National Academy of Science 97(21):11343-11347.

CRANFORD, T. W., M. AMUNDIN AND K. S. NORRIS. 1996. Functional morphology and homology in the odontocete nasal complex: Implications for sound generation. Journal of Morphology 228:223-285.

DALL, W. H. 1909. Report on a collection of shells from Peru, with a summary of the littoral marine Mollusca of the Peruvian Zoological Province. Proceedings of the United States National Museum 37:147-294.

Deméré, T., A. BerTa AND P. ADAms. 2003. Pinnipedimorph evolutionary biogeography. Bulletin of the American Museum of Natural History 13(279):32-76.

EKMAN, S. 1953. Zoogeography of the sea. Sidgwick \& Jackson, London, UK.

EscorZA-Treviño, S., L. A. PASTENE AND A. E. DizON. 2004. Morphological analyses of the truei and dalli morphotypes of Dall's porpoise (Phocoenoides dalli). Journal of Mammalogy 85:21-29.

FELSENSTEIN, J. 1985. Confidence limits on phylogenies: An approach using bootstrap. Evolution 39:783-91.

Fraser, F. C. 1966. Comments on the Delphinoidea. Pages 7-31 in K. S. Norris, ed. Whales, dolphins and porpoises. University of California Press, Berkeley, CA.

Fraser, F. C., AND P. E. Purves. 1960. Hearing in Cetaceans: Evolution of the accessory air sacs and the structure and function of the outer and middle ear in recent Cetaceans. Bulletin of the British Museum (Natural History) 7(1):1-140.

GARTH, J. S. 1957. Reports of the Lund University Chile Expedition 1948-49. 29. The Crustacea Decapoda Brachyura of Chile. Lunds Universitets Arsskrift, N.F. Avd. 2. Bd. $537: 1-130$.

GASKIN, D. E. 1976. The evolution, zoogeography and ecology of Cetacea. Oceanography and Marine Biology. Annual Reviews 14:247-346.

Gaskin, D. E., P. W. ARNOLD AND B. A. Blair. 1974. Phocoena phocoena. Mammalian Species 42:1-8.

Gaskin, D. E., G. J. D. Smith, A. P. Watson, W. Y. Yasui And D. B. Yurick. 1984. Reproduction in the porpoises (Phocoenidae): Implications for management. Report of the International Whaling Commission (Special Issue 6):135-148.

Geisler, J. H., AND A. E. SANDERS. 2003. Morphological evidence for the phylogeny of Cetacea. Journal of Mammalian Evolution 10(1/2):23-129.

GoOdAll, R. N. P., AND A. C. M. SChiavini. 1995. On the biology of the spectacled porpoise, Australophocaena dioptrica. Report of the International Whaling Commission (Special Issue 16):411-453.

GRAY, J. E. 1825. An outline of an attempt at the disposition of Mammalia into tribes and families, with a list of the genera apparently appertaining to each tribe. Annals of Philosophy 26(6):337-344 (vol. 10 of new series).

Hamilton, H., S. Caballero, A. G. Collins and R. L. Brownell JR. 2001. Evolution of river dolphins. Proceedings of the Royal Society of London 268:549-556.

HEYNING, J. E. 1989. Comparative facial anatomy of beaked whales (Ziphiidae) and a systematic revision among the families of extant odontoceti. Los Angeles County Museum Contributions in Science 405:1-64.

Heyning, J. E. 1997. Sperm whale phylogeny revisited: Analysis of the morphological evidence. Marine Mammal Science 13:596-613. 
HICKMAN, C. S., AND J. H. MCLEAN. 1990. Systematic revision and suprageneric classification of trochacean gastropods. Natural History Museum of Los Angeles County. Science Series, Special Publication 35:1-169.

Howell, A. B. 1927. Contribution to the anatomy of the Chinese finless porpoise, Neomeris phocaenoides. Proceedings of the United States National Museum 70(13):1-43.

HuBBS, C. L. 1952. Antitropical distribution of fishes and other organisms. Proceedings of the Seventh Pacific Science Congress 3:324-329.

ICHISHIMA, H., AND M. KIMURA. 2000. A new fossil porpoise (Cetacea; Delphinoidea; Phocoenidae) from the early Pliocene Horokaoshirarika Formation, Hokkaido, Japan. Journal of Vertebrate Paleontology 20(3):561-590.

ICHISHIMA, H., AND M. KIMURA. 2005. Haborophocoena toyoshimai, a new early Pliocene porpoise (Cetacea: Phocoenidae) from Hokkaido, Japan. Journal of Vertebrate Paleontology 25(3):655-664.

Jacobs, D. K., T. A. Haney And K. D. Louie. 2004. Genes, diversity, and geologic process on the Pacific coast. Annual Review of Earth and Planetary Sciences 32:601-652.

Jefferson, T. A. 1988. Phocoenoides dalli. Mammalian Species 319:1-7.

JEFFERSON, T. A. 1990. Sexual dimorphism and development of external features in Dall's porpoise Phocoenoides dalli. Fishery Bulletin, U.S. 88:119-132.

JEFFERSON, T. A. 2002. Preliminary analysis of geographic variation in cranial morphometrics of the finless porpoise (Neophocaena phocaenoides). The Raffles Bulletin of Zoology 10: $3-14$.

JefFerson, T. A., AND M. W. NewCOMER. 1993. Lissodelphis borealis. Mammalian Species 425:1-6.

KASUYA, T. 1973. Systematic consideration of recent toothed whales based on the morphology of tympano-periotic bone. Scientific Reports of the Whales Research Institute 25: 1-103.

KellogG, R. 1928. The history of whales-their adaptation to life in the water. Quarterly Review of Biology 3:29-76.

KING, J. E. 1983. Seals of the world, 2nd edition. Cornell University Press, Ithaca, NY.

Knies, J., J. MATthiEssen, C. Vogt AND R. STEIN. 2002. Evidence of "Mid-Pliocene ( 3Ma) global warmth" in the eastern Arctic Ocean and implications for the Svalbard/Barents Sea ice sheet during the Pliocene and early Pleistocene ( 3-1.7Ma). Boreas 31:82-93.

LeDuc, R. G., W. F. PERrin AND A. E. DizON. 1999. Phylogenetic relationships among the delphinid cetaceans based on full cytochrome b sequences. Marine Mammal Science 15:619-648.

LeAtherwoOd, S., AND R. R. ReEves. 1983. The Sierra Club handbook of whales and dolphins. Sierra Club Books, San Francisco, CA.

LINDBERG, D. R. 1991. Marine biotic interchange between the northern and southern hemispheres. Paleobiology 17(3):308-324.

MABEE, P. M., AND J. HuMPHRIES. 1993. Coding polymorphic data: Examples from allozymes and ontogeny. Systematic Biology 42:166-181.

MADDISON, D. R., AND W. P. MADDISON. 2000. MacClade, Version 4. Sinaeur Associates Inc., Sunderland, MA.

Maddison, W. P., M. J. Donoghue AND D. R. MADDison. 1984. Outgroup analysis and parsimony. Systematic Biology 33:83-103.

MARTINS, E. P., AND T. F. HANSEN. 1997. Phylogenies and the comparative method: A general approach to incorporating phylogenetic information into the analysis of interspecific data. American Naturalist 149:646-667.

MEAD, J. G. 1975. Anatomy of the external passages and facial complex in the Delphinidae (Mammalia: Cetacea). Smithsonian Contributions to Zoology 207. 72 pp.

Messenger, S. L., AND J. A. MCGuire. 1998. Morphology, molecules, and the phylogenetics of Cetaceans. Systematic Biology 47:90-121.

MiLler, G. S. JR. 1923. The telescoping of the cetacean skull. Smithsonian Miscellaneous Collections 76:1-55. 
Muizon, DE C. 1984. Les vertebrates fossiles de la Formation Pisco (Perou). Part II: Les Odontocetes (Cetacea: Mammalia) du Pliocene Inferieur de Sud-Sacaco. Editions Recherche sur les Civilisations Memoire 50:1-188.

MuizON, DE C. 1988. Les relations phylogenetiques des Delphinida (Cetacea: Mammalia). Annales de Paleontologies 74:159-227.

Noble, B. A., AND F. C. FRASER. 1971. Description of a skeleton and supplementary notes on the skull of a rare porpoise Phocoena sinus Norris and McFarland, 1958. Journal of Natural History London 5:447-464.

NORRIS, K. S., AND W. N. MCFARLAND. 1958. A new harbor porpoise of the genus Phocoena from the Gulf of California. Journal of Mammalogy 39:22-39.

O'Leary, M. A., M. Allard, M. J. Novacek, J. Meng AND J. Gatesy. 2004. Building the mammalian sector of the tree of life. Pages 490-516 in J. Cracraft and M. J. Donoghue, eds. Assembling the tree of life. Oxford University Press, Oxford, UK.

PERrin, W. F., AND P. E. ROSEL. 1999. Cranial features in the phocoenids consistent with their molecular phylogeny, or can one bias help balance out another?. Abstract, 13th Biennial Conference on the Biology of Marine Mammals, Maui, HI, 29 November-3 December 1999.

PILLERI, G., AND P. CHEN. 1980. Neophocaena phocaenoides and Neophocaena asiaeorientalis: Taxonomical differences. Investigation on Cetacea 11:25-32.

PILLERI, G., AND M. GIHR. 1972. Contribution to the knowledge of the cetaceans of Pakistan with particular reference to the genera Neomeris, Sousa, Delphinus and Tursiops and description of a new Chinese porpoise (Neomeris asiaeorientalis). Investigation on Cetacea 4:107-162.

PILLERI, G., AND M. GIHR. 1975. On the taxonomy and ecology of the finless black porpoise, Neophocaena (Cetacea, Delphinidae). Mammalia 39:657-673.

RALLS, K., AND S. L. MeSNICK. 2002. Sexual dimorphism. Pages 1071-1078 in W. F. Perrin, B. Würsig and J. G. M. Thewissen, eds. Encyclopedia of marine mammals. Academic Press, San Diego, CA.

READ, A. J. 1999. Harbour porpoise Phocoena phocoena (Linnaeus, 1758). Pages 323-355 in S. H. Ridgway and R. Harrison, eds. Handbook of marine mammals. Volume 6. The second book of dolphins and the porpoises. Academic Press, San Diego, CA.

Reeves, R. R., B. S. Stewart, P. J. Clapham, J. A. Powell and P. A. Folkens. 2002. Guide to marine mammals of the world. Alfred A. Knopf, Inc., New York, NY.

REYES, J. C., AND K. VAN WAEREBEEK. 1995. Aspects of the biology of Burmeister's porpoise from Peru. Report of the International Whaling Commission (Special Issue 16):349364.

RICE, D. W. 1967. Cetaceans. Pages 291-324 in S. Anderson and J. K. Jones JR., eds. Recent mammals of the world. A synopsis of families. The Ronald Press Co, New York, NY.

RICE, D. W. 1998. Marine mammals of the world: Systematics and distribution (Special Publication No. 4). Society for Marine Mammalogy, Lawrence, KS.

Rokas, A., B. L. Williams, N. King AND S. B. CARroll. 2003. Genome-scale approaches to resolving incongruence in molecular phylogenies. Nature 425:798-804.

Rommel, S. A. 1990. Osteology of the bottlenose dolphin. Pages 29-48 in S. Leatherwood and R. Reeves, eds. The bottlenose dolphin. Academic Press, San Diego, CA.

Rosel, P. E., A. E. DizON AND M. G. HAYGOOD. 1995a. Variability of the mitochondrial control region in populations of the harbour porpoise, Phocoena phocoena, on interoceanic and regional scales. Canadian Journal of Fisheries and Aquatic Sciences 52:1210 1219.

Rosel, P. E., M. G. Haygood AND W. F. Perrin. 1995b. Phylogenetic relationships among the true porpoises (Cetacea: Phocoenidae). Molecular Phylogenetics and Evolution 4:463-474.

SCHENKKAN, E. J. 1971. The occurrence and position of the "connecting sac" in the nasal tract complex of small odontocetes (Mammalia, Cetacea). Beaufortia 246:37-43. 
Shirakihara, M., A. Takemura And K. Shirakihara. 1993. Age, growth and reproduction of the finless porpoise, Neophocaena phocaenoides, in the coastal waters of western Kyushu, Japan. Marine Mammal Science 9:392-406.

SOOT-RYEN, T. 1959. Reports of the Lund University Chile Expedition 1948-49.35. Pelecypoda. Lunds Universitets Arsskrift, N. F. Avd. 2. Bd. 55 6:1-86.

STACEY, P. J., AND P. W. ARNOLD. 1999. Orcaella brevirostris. Mammalian Species 616:1-8.

SWOFFORD, D. L. 2000. PAUP* Phylogenetics using Parsimony (*and other methods), Version 4.0. Sinaeur Associates, Sunderland, MA.

SwOFFORD, D. L., AND S. H. BERLOCHER. 1987. Inferring evolutionary trees from gene frequency data under the principle of maximum parsimony. Systematic Zoology 36:293325 .

Wadell, V. G., M. C. Milinkovitch, M. Berube and M. J. Stanhope. 2000. Molecular phylogenetic examination of the Delphinoidea trichotomy: Congruent evidence from three nuclear loci indicates that porpoises (Phocoenidae) share a more common ancestry with white whales (Monodontidae) than they do with true dolphins (Delphinidae). Molecular Phylogenetics and Evolution 15(2):314-318.

WANG, P., F. XIANG AND X. LIU. 1989. A study of finless porpoise in China. Fisheries Science 11:4-9.

WATROUS, L. E., AND Q. D. WHEELER. 1981. The out-group comparison method of character analysis. Systematic Zoology 30:1-11.

WeAver, A. J. 1990. Ocean currents and climate. Nature 347:432.

WIENS, J. J. 1999. Polymorphism in systematics and comparative biology. Annual Review of Ecology and Systematics 30:327-362.

WIENS, J. J. 2004. The role of morphological data in phylogeny reconstruction. Systematic Biology 53(4):653-661.

WiLsOn, L. E. 1973. A delphinid (Mammalia, Cetacea) from the Miocene of Palos Verdes Hills, California. University of California Publications in Geological Sciences 103:1-34.

Received: 26 September 2005

Accepted: 21 March 2006

\section{SUPPLEMENTARY MATERIAL}

The following supplementary material is available for this article online:

Supplementary Appendix 1

Supplementary Appendix 2

Supplementary Appendix 3 